\title{
INTEGRATING THEORY AND PRACTICE IN BUSINESS EDUCATION
}

\author{
Dr. Otto F. Von Feigenblatt ${ }^{1}$ : Northwood University (West Palm Beach, Florida) \\ profvonfeigenblatt@hotmail.com
}

The review examines the relationship between theory and practice in business education. Using academic articles as reading materials for both undergraduate and graduate students is recommended as a way to elucidate the direct connection between theory development in academia and practice in the business world. It is concluded that the integration of theory and practice in Business education is not only necessary due to functional reasons but rather a necessity in order to foster the formation of ethical and well-rounded leaders.

One of the most widespread misconceptions in the Business World is that theory and practice are inherently different and disconnected, not only in terms of form but also in essence. This is particularly surprising when popular business terms such as TQM (Total Quality Management) and Human Capital started their lives far away from the bustling of the factory floor and a great distance from the glossy clear surface of the executive desk (Stewart \& Knowles, 2003). Most business terms, models, and theories start their lives in the messy desks, quiet libraries, and convoluted mental meanderings of university academics (Creswell, 2007; Jordan, 2003). If the origin of most business ideas follows the traditional path of knowledge formation, from the Ivory Tower to Main Street then what explains the collective delusion that knowledge creation in business is any different from that in other disciplines like Engineering and the natural Sciences? I tentatively posit that part of the answer resides in the relatively recent methodological divergence in terms of teaching between Business, Medicine, and other applied disciplines on one side and the Liberal Arts such as the Social and the Natural Sciences on the other hand.

\section{Exploring business education}

It should be noted that while research pertaining to business is nothing new and can be traced to Adam Smith and his colleagues of the Edinburgh School in the $18^{\text {th }}$ century, the interdisciplinary discipline of Business Administration is relatively new and borrows theories from a range of Liberal Arts disciplines such as Economics,

\footnotetext{
${ }^{1}$ Nombre y Apellidos del autor de contacto: Northwood University (West Palm Beach, Florida) profvonfeigenblatt@hotmail.com
} 
Sociology, Psychology, Political Science, and recently even from Cultural Anthropology (Jordan, 2003). Due to the eclectic nature of Business related research and its debt to a range of different disciplines, business education tends to be structured around practical topics rather than around clearly integrated theoretical paradigms. The unintended result of this is that students are presented with a diverse set of theories and models to deal with particular practical issues but the origin of the models and the relationship between the theories are not explained. Oftentimes this emphasis on theories as disjointed tools to deal with specific and oftentimes mundane issues results in a lack of understanding of the reasons why the theories work and most importantly in an inability to combine and adapt the different theories to solve new or unusual problems. Nevertheless, a topical approach or even a case study approach to education need not result in the aforementioned compartmentalization of knowledge. Instead, a properly integrated and well implemented topical approach can result in a clearly communicated connection between theory and practice, and thus engender well-rounded scholar-practitioners.

An important negative externality of the proletarianization of business education is the perceived gap between research and practice held by a broad section of business, in particular among lower level management and small entrepreneurs, who while applying important business models and techniques developed in academia, lack an understanding of how basic and applied research directly benefits the private sector. While it is beyond the purview of the present article to explain the tortuous and at times unexpected paths popular business techniques follow from their ethereal cradles to their greasy graves, a brief description of a traditional path is in order.

A theory tends to start as a fussy idea of the relationships between two phenomena in the head of either a university professor or a graduate student (Creswell, 2007; Willis, 2007). The relationship is then tested, described, explained, and developed into a formal model. For a theory to become a formal theory it must be accepted by and shared with the rest of the academic community. Formal theories are shared through publication in academic journals, academic conferences, dissertations, and monographs (single volume studies) which are reviewed and critiqued by other experts. Business consultants, business editors, and every now and then journalists read those journals, attend those conferences, and ready those monographs. The most useful theories are then summarized and operationalized before being included in trade magazines such as Forbes, the Wall Street Journal, and the Economist. Trade Magazines are influential among corporate executives, policy leaders, and financial analysts who then apply and test those theories and techniques on their organizations. Successful models are then emulated by smaller businesses and less attentive executives. Therefore there is a trickle down process from academia to the business world and subsequently feedback in the form of success or failure in the process of implementation. Thus, the process functions as a cycle of "creative destruction" feeding a constant pursuit of better models and increasingly effective business techniques. 
Now that a clear link between academia and business has been established, it is time to turn to the anomalous belief in their incommensurability and lack of crossfertilization between the two. As posited in the introduction to this essay, the incommensurability/disconnection fallacy can be partly attributed to recent trends in business education in addition to the lagging professionalization of the managerial corps in the small and possibly medium sized business levels. While the lack of widespread formal business education in small businesses is an important challenge that needs to be tackled and remedied in due time, it is beyond the scope of the present paper. It will suffice to mention the fact that most small entrepreneurs lack a formal business background and that successful ones tend to either hire people with one or pursue one on their own as their business prospers.

Business education has the potential to provide more than just useful techniques to future business leaders but rather has the potential to transform students into well rounded citizens leading socially indispensable organizations for the sustainable benefit of their societies. This requires a much more holistic view of business which in turn rests on a better understanding of the nexus between theory and practice. While the previously mentioned lofty goal may seem overly ambitious, one should remember that the original goal of higher education in the United States was always the "bildung" (cultivation) or social growth of the individual with the learning of a trade simply being a secondary positive externality (Lueddeke, 2008; Sorkin, 1983). Evidence of the previous assertion can be found in the general education requirements of the American bachelor's degree which includes subjects such as Art History, Political Science, and Sociology, inter alia (Aud et al., 2011).

In order to integrate theory and practice it is necessary to expose students to a wide range of texts including trade magazines, textbooks, case studies, and most importantly journal articles. While academic articles are written in specialized jargon, students can be taught the terms before reading the texts in question. Moreover, requiring students to read advanced academic articles can also help "scaffold" students to higher reading and writing levels. It is important to provide the proper guidance and support during this process so that the student can understand the most important concepts in the article without becoming frustrated. Reading academic articles at the undergraduate level also provides students with a rare glimpse into the process of knowledge creation while concurrently providing clear examples of how theory shapes practice (Rogers, 1996).

If properly implemented, the inclusion of academic articles in undergraduate business courses, students can increase their sense of self-competency, their understanding of the process of knowledge creation, and most importantly the link between theory and practice. In order to cement the important insights that students gain from their exposure to the academic literature it is useful to require assignments that ask students to apply the theories to their own lives and experiences (Bain, 2004). Professor Dr. Clayton M. Christensen of the Harvard Business School has popularized this approach in his lectures and recently in his bestselling book titled "How will you measure your life? (2012)" In his popular book, Dr. Christensen makes the important distinction between having an opinion and providing a 
recommendation based on a theory when he aptly states that "I don't have an opinion, the theory has an opinion" (2012, p. 12), in order to separate advice based on experiential opinion and theoretical conclusions based on sound research. Students need to understand the difference between the two and one of the best ways to do so is to show them how theories are created and most importantly how they can be applied to a varied set of phenomena. By doing this, students will be able to reassess the relationship between theory and practice.

\section{Conclusive evidence}

While the link between theory and practice is a complex one, it is undeniable that they are inextricable and interdependent. Exposing students to this complexity not only makes them better problem solvers and thus better managers and entrepreneurs, but also better citizens who can see beyond the narrow confines of their industry and business. If at least one student per cohort asks "So Bob, is that your opinion or do you have evidence and a theory to back it up?" in a future board meeting, then we can consider ourselves successful. If we can also prevent a few corporate scandals, human rights abuses, and "unintended" economic bubbles, even better.

\section{Reference}

Books, book chapters or entry of a reference bock, technical reports, theses

Bain, Ken. (2004). What the Best College Teachers Do. Cambridge: Harvard University Press.

Christensen, Clayton M. (2012). How will you measure your Life? New York: Harper Business.

Creswell, John W. (2007). Qualitative Inquiry \& Research Design: Choosing Among Five Approaches (Second ed.). London: SAGE Publications.

Jordan, Ann T. (2003). Business Anthropology. Long Grove: Waveland Press, Inc.

Lueddeke, George. (2008). Reconciling Research, Teaching and Scholarship in Higher Education: An Examination of Disciplinary Variation, the Curriculum and Learning. International Journal for the Scholarship of Teaching and Learning, 2(1), 1-18.

Rogers, Alan. (1996). Teaching Adults (Second ed.). Philadelphia: Open University Press.

Willis, Jerry W. (2007). Foundations of Qualitative Research: Interpretive and Critical Approaches. London: SAGE Publications. 


\section{Periodicals, magazines, and similar webes}

Aud, Susan, Hussar, William, Kena, Grace, Bianco, Kevin, Frohlich, Lauren, Kemp, Jana, ... Mallory, Katie. (2011). The Condition of Education 2011. Washington D.C.: Department of Education Retrieved from http://nces.ed.gov/pubsearch/pubsinfo.asp?pubid=2011033

Sorkin, David. (1983). Wilhelm von Humbolt: The Theory and Practice of SelfFormation (Bildung), 1791-1810. Journal of the History of Ideas, 44(1), 55-73.

Stewart, Jim, \& Knowles, Vanessa. (2003). Mentoring in undergraduate business management programmes. Journal of European Industrial Training, 27(2-4), 147-159. 